\title{
Floristic analysis of semi-arid mountain ecosystems of the Griqualand West centre of plant endemism, Northern Cape, South Africa
}

\author{
NANETTE VAN STADEN ${ }^{1, \boldsymbol{v}}$, STEFAN JOHN SIEBERT ${ }^{1}$, DIRK PETRUS CILLIERS ${ }^{1}$, DIAN WILSENACH ${ }^{1}$, \\ ARNOLD WALTER FRISBY ${ }^{2}$ \\ ${ }^{1}$ Unit for Environmental Sciences and Management, Faculty of Natural and Agricultural Sciences, North-West University. Potchefstroom Campus, \\ Hoffman Street 11, Potchefstroom 2531, South Africa. Tel.: +27-860-169698. `email: nanette.van.staden@gmail.com \\ ${ }^{2}$ Department of Plant and Soil Sciences, Faculty of Natural and Agricultural Sciences, University of Pretoria. Cnr Lynnwood Road and Roper Street, \\ Hatfield, Pretoria 0028, South Africa
}

Manuscript received: 24 February 2020. Revision accepted: 14 April 2020.

\begin{abstract}
Van Staden N, Siebert SJ, Cilliers DP, Wilsenach D, Frisby AW. 2020. Floristic analysis of semi-arid mountain ecosystems of the Griqualand West centre of plant endemism, Northern Cape, South Africa. Biodiversitas 21: 1989-2002. The Griqualand West Centre (GWC) is one of 13 centres of plant endemism in South Africa. Despite its unique flora, it remains poorly conserved and studied. A recent study identified an extensive geographical core area for the GWC, but endemic plant species were found to be absent from certain parts within these borders. To address this, we refined the current GWC borders based on an ecological niche model, which predicted that endemic species are restricted to four mountain ranges within GWC. Mountain floras within these refined borders were then floristically compared to assess whether they are hotspots of endemicity. Floristically, the Asteraceae, Fabaceae, Malvaceae, and Poaceae were the dominant plant families. Mountain ecosystems differed from one another at species level, with indicator species explaining the compositional differences. Distribution patterns of indicator species were determined by mean annual precipitation, Ca: $\mathrm{Mg}$ ratios, soil $\mathrm{pH}$, cation exchange capacity, iron, and sand content. These environmental factors are possible drivers of niche partitioning, environmental filtering and habitat specialization in each mountain ecosystem. Limestone and banded ironstone habitats were identified as conservation priority areas, since they contained the highest numbers of rare and threatened GWC restricted-range species, of which six were narrow endemics.
\end{abstract}

Keywords: Asbestos, banded iron formation, Ghaap Plateau, Kuruman, limestone, quartzite

Abbreviations: ANOVA: Analysis of Variance; AUC: Area Under Curve; CCA: Canonical Correspondence Analysis; CEC: Cation Exchange Capacity; EC: Electrical Conductivity; GWC: Griqualand West Centre of Endemism; GW: Griqualand West; MAP: Mean Annual Precipitation; MAT: Mean Annual Temperature; MaxEnt: Maximum entropy; NMDS: Non-metric Multi-Dimensional Scaling; PERMANOVA: Permutational Multivariate Analysis of Variance; QDG: Quarter-Degree Grid; SAWS: South African Weather Service; XRF: X-ray fluorescence

\section{INTRODUCTION}

Mountain ecosystems are characterized by distinct floras (Harrison et al. 2009) due to habitat heterogeneity (Noroozi et al. 2018; Chakraborty 2019). Mountains are therefore considered to function like edaphic islands (Rajakaruna 2004), with specific microclimates and habitats to which plant species are adapted by developing special traits (Rajakaruna 2004; Rajakaruna 2018), resulting in speciation and species-rich floras (Kruckeberg 1969). Many unique edaphic floras of mountain ecosystems have been found to be associated with centres of endemism (Van Wyk and Smith 2001; Williamson and Balkwill 2015; Noroozi et al. 2018). Edaphic floras are therefore rich in endemic, edaphic specialists (Schmiedel and Jürgens 1999; Siebert et al. 2002). This phenomenon is typical for banded ironstone (Jacobi et al. 2007; Markey and Dillon 2010), quartzite (Schmiedel and Jürgens 1999; Curtis et al. 2013), and carbonate soils (Peñas et al. 2005; Siebert and Siebert 2005; Mota et al. 2008). Mountain floras of GWC are characterized by these rock types (Frisby et al. 2019), and has a heterogeneous undulating landscape with diverse climate and unique vegetation types (Mucina and Rutherford 2006). Despite GWC's distinct vegetation, and known endemic flora of 24 endemics and two nearendemic plant species (Frisby et al. 2019), our understanding regarding its plant diversity patterns is limited. Botanical studies in GWC are few (Wilman 1946; Mostert 1967; Frisby et al. 2019; Van Munster et al. 2019) and, hence, a descriptive assessment of the endemic edaphic flora across different mountain geologies of GWC is required to encourage conservation initiatives (Table 1).

Globally, centres of endemism are inadequately conserved with some regions not being included within borders of protected areas (Millar et al. 2017). Hence, centres of endemism should garner more conservation attention and it is, therefore, essential to understand the patterns and drivers of endemism (Noroozi et al. 2018; Taylor-Smith et al. 2020). Accurate identification of the floristic borders of centers of endemism is imperative to aid with designs for effective and strategic biodiversity conservation and management (Wang et al. 2020). Accurate demarcation of centres of endemism at a finer scale is necessary to ensure comprehensive conservation 
and management of species to be protected (Cañadas et al. 2014). Endemic species have the potential to serve as flagship species, and conservation action will become more effective by focusing on regions where endemics occur exclusively (Noroozi et al. 2018; Taylor-Smith et al. 2020). This seems logical especially when funding for conservation is limited (Margules and Pressey 2000).

This study was conducted to promote conservation strategies by providing conservation authorities with detailed information to ensure proper conservation of GWC, by focusing on priority areas where endemic species occur at a finer scale. This paper addresses two primary aims to develop a better understanding of the GWC and its flora. Firstly, the borders of GWC are refined to establish which main mountain ranges fall within the centre by using a MaxEnt spatial model based on geology, climate, and topography in combination with distribution data of GWC endemics. Refining the borders of GWC will (i) result in a smaller geographical region that will allow for focused botanical studies and, (ii) ensure targeted conservation of endemic plant species. Secondly, the flora associated with the main mountain ecosystems within these newly refined borders will be described. By doing so, knowledge regarding floristic characteristics of the ecosystems will depict the distinctness of the mountain floras. Mountain floras will be described based on (i) dominant plant families, (ii) common species, (iii) indicator plant species, (iv) threatened and endemic species, and (v) species composition.

\section{MATERIALS AND METHODS}

\section{Study area}

GWC was first proposed and mapped by Van Wyk and Smith (2001). Recently, borders were described and set by Frisby et al. (2019). This description was based on QDG's of the total distribution of GWC endemic species per se, which resulted in an extensive area $\left(75172 \mathrm{~km}^{2}\right)$.

The GWC falls within the Savanna Biome. The landscape is heterogenous with mountain ranges and/or ridges trending north-south (Figure 1), with the intermontane valleys filled with Kalahari sands (Mucina and Rutherford 2006). In the east, GWC consists of the dolomitic Ghaap Plateau bordering on an undulating set of low banded ironstone hills called the Asbestos- and Kuruman Hills. The landscape becomes more rugged in the west of GWC due to the quartzitic Langberg. These mountain systems are each characterized by endemic vegetation units, i.e. Ghaap Plateau Vaal Bushveld,
Kuruman Mountain Bushveld, and Koranna-Langberg Mountain Bushveld (Mucina and Rutherford 2006).

\section{Climate}

GWC falls within the summer rainfall region of South Africa. Rainfall is highly erratic, and a semi-arid climate prevails. From east to west, a gradient of increasing aridity is evident. In the east, the Ghaap Plateau receives higher rainfall, whereas the Langberg in the west is a region of lower, more arid rainfall (Table 1). The Kuruman Hills receive higher rainfall than the southern Asbestos Hills of the same geology (Mucina and Rutherford 2006). The mountains are slightly cooler than the lower-lying areas (Mucina and Rutherford 2006; Frisby et al. 2019).

\section{Geology and soil}

Three subgroups of the Ghaap Group (Griqualand West Basin) are found in GWC, namely Campbell Rand, Schmidtsdrif and Asbestos Hills (Van Wyk and Smith 2001; Eriksson et al. 2006). The former two subgroups dominate on the Ghaap Plateau. Soils are rich in lime due to the prevalence of dolomite, limestone, and chert (Keyser 1997). Therefore, the soil of the Ghaap Plateau is rich in both magnesium $(\mathrm{Mg}$ ) and calcium $(\mathrm{Ca})$ (McCarthy and Rubidge 2005). On dolomites, soils are sandy and dark brown to reddish, while shallow, black, turfy and alkaline soils are found on limestone. Furthermore, the soil is underlain by weathered rock and slightly leached (Mucina and Rutherford 2006; AGIS 2007).

The Asbestos Hills subgroup dominates on the Kuruman- and Asbestos Hills that consist mainly of banded ironstone. Additionally, jaspillite, chert and riebeckite asbestos are associated with these two mountain ecosystems (Keyser 1997; Mucina and Rutherford 2006). Soils are sandy and shallow with $60-80 \%$ of the soil surface covered with boulders or rocks (Mucina and Rutherford 2006; AGIS 2007).

The geology of the Langberg consists of clastic sediments such as quartzite (white, pink and green), greywacke, lavas, conglomerate, and hematite of the Olifantshoek Supergroup (Keyser 1997; Mucina and Rutherford 2006). Arenaceous rocks (derived from or containing sand) of the Volop Group are well exposed in the landscape with red-brown arenites of the Matsap Subgroup overlying the Hartley Formation, which is a layer of conglomerate (Moen 2006). Slopes are steep (mostly 10$50^{\circ}$ ) with limited soil cover. Soils are rocky with exposed boulders and/or rocks covering more than $80 \%$ of the landscape (AGIS 2007). Soil texture varies from sandy loam to sandy clay loam (AGIS 2007).

Table 1. Summary of environmental conditions associated with each GWC mountain landscape (Mucina and Rutherford 2006)

\begin{tabular}{llllll}
\hline Mountain & Approx. area $\left.\mathbf{( k m}^{2}\right)$ & $\begin{array}{l}\text { Altitude } \\
(\mathbf{m . a . s . l .})\end{array}$ & $\begin{array}{l}\text { MAT } \\
\left({ }^{\circ} \mathbf{C}\right)\end{array}$ & $\begin{array}{l}\text { MAP } \\
(\mathbf{m m})\end{array}$ & Geology \\
\hline Ghaap Plateau & 14997 & $1100-1500$ & 17.1 & $370-425$ & Dolomite, limestone \\
Kuruman Hills & 1236 & $1100-1800$ & 16.8 & $355-375$ & Banded ironstone \\
Asbestos Hills & 2117 & $1100-1800$ & 16.8 & $290-360$ & Banded ironstone \\
Langberg & 1204 & $1000-1850$ & 16.8 & $225-295$ & Quartzite \\
\hline
\end{tabular}

Note: Abbreviations in the table are as follows: Meters above sea level (m.a.s.l.), Mean annual temperature (MAT) and Mean annual precipitation (MAP). 

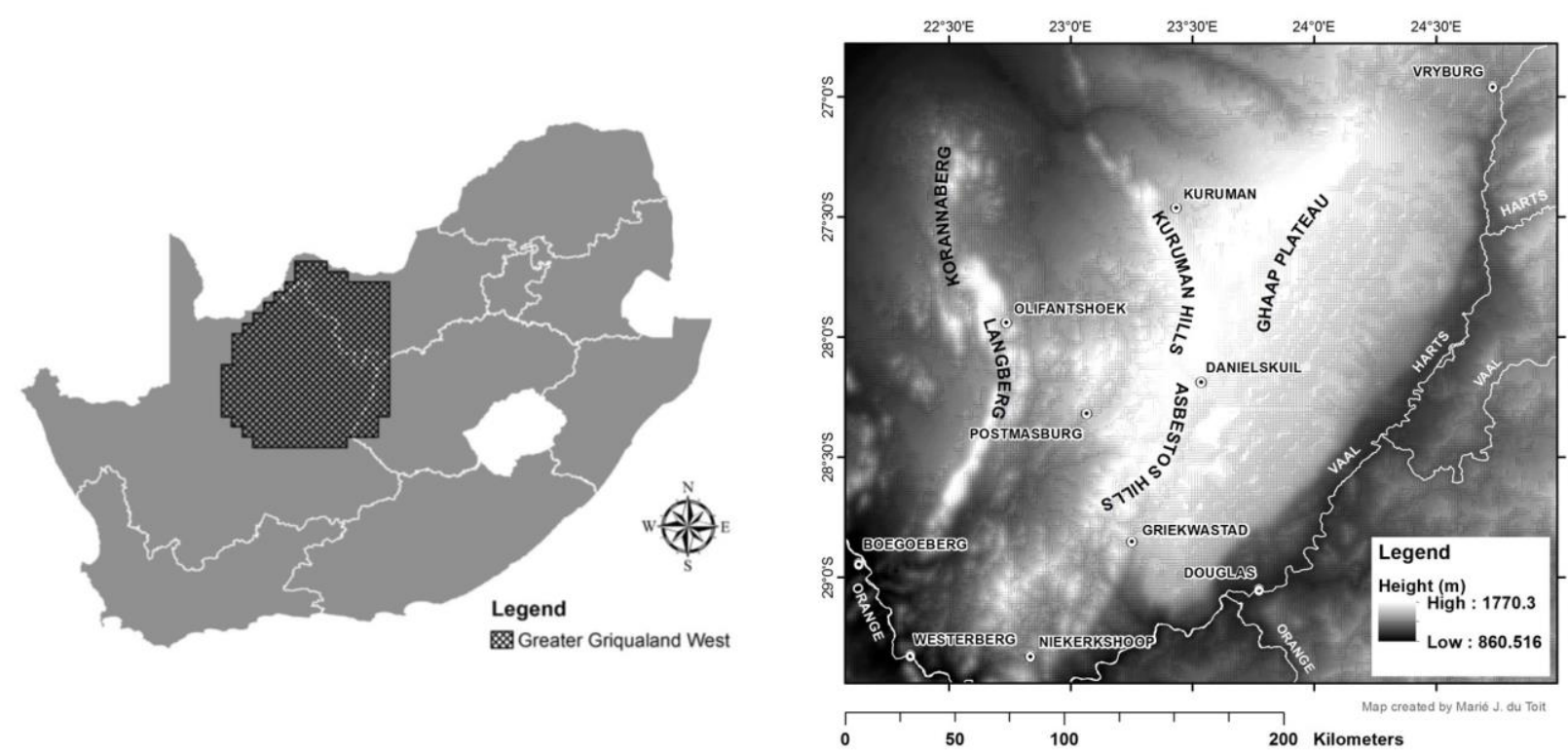

Figure 1. Main mountain ranges in GWC in the Greater Griqualand West area, Northern Cape, South Africa. The Langberg extends ultimately into the Korannaberg in the north. Since the Korannaberg falls outside the center and does not harbor any GWC endemics, this range was excluded from this study

\section{Data collection and -analysis Refining the borders}

MaxEnt software (Elith et al. 2011; Phillips et al. 2019) was used to develop an ecological niche model for GWC based on bioclimatic variables. MaxEnt uses probability of occurrence to calculate the conditions in which species occur (Phillips et al. 2009). A total of 95 verified occurrence records for 24 endemics and two near-endemic species identified by Frisby et al. (2019) were used as presence records in the model. A total of 19 bioclimatic variables obtained from WorldClim version 2 (Fick and Hijmans 2017) represented environmental conditions (See supplementary, Table A1). An $80 / 20$ split was applied to the occurrence records, with $80 \%$ of records $(n=76)$ used to train the model and $20 \%(n=19)$ used to test the accuracy of the model prediction. Default settings were used, except for the replication number that was set to 100. The AUC score was used to determine the accuracy of the model (Bean et al. 2012), where an AUC of 1 would indicate a perfect prediction and 0.5 a random prediction (Phillips et al. 2006). An AUC of 0.979 was obtained suggesting a good model prediction. To convert the model output to a binary output usable for delineation purposes, a threshold was applied. The tenth percentile training presence logistic threshold (0.2772), that is suitable to (i) use when dealing with centres of endemism (Escalante et al. 2013) as well as (ii) studies relying on presence-only data (Callen and Miller 2015), was used. The binary output was finally intersected with the boundary delineated by Frisby et al. (2019) as well as the geology (See supplementary, Table A2) preferred by endemics in GWC.

\section{Floristic analysis}

Historical data

Species lists for GWC were obtained from BODATSA (Ranwashe 2019). This data was supplemented with specimen records obtained from herbaria with collections from the GW region, including PUC, KMG, PRU, KSAN, NMB, BLFU, and PRE. All distribution data were captured at species level at QDG resolution. Further distribution data were supplemented from literature sources (Van Wyk and Smith 2001; Mucina and Rutherford 2006).

\section{Field sampling}

The four mountain ecosystems within the refined border of the GWC were sampled in the wet season. Total rainfall, obtained from the SAWS for January to April 2018 (sampling year), ranged between $160.6 \mathrm{~mm}$ and $422.4 \mathrm{~mm}$ (west to east). A total of eight Modified-Whittaker plots $(50 \mathrm{~m} \times 20 \mathrm{~m})$ were sampled per mountain system. The $50 \mathrm{~m}$ sides of transects were placed parallel to the slope of the mountain with the $20 \mathrm{~m}$ sides perpendicular to the $50 \mathrm{~m}$ sides. Two $1 \mathrm{~m}^{2}$ sub-plots were sampled within two opposite corners of the plot. All rooted herbaceous individuals within sub-plots were identified up to species level and counted. Soil samples were collected for each Modified-Whittaker plot and five soil samples were randomly collected at a depth of $0-10 \mathrm{~cm}$, depending on soil depth due to rockiness. From this, a composite sample was compiled and thoroughly mixed. Macro-and micronutrients of soil samples were analyzed using a portable XRF analyzer (Koch et al. 2017). Particle size distribution, soil $\mathrm{pH}, \mathrm{EC}, \mathrm{CEC}$, percentage clay, and silt were analyzed according to procedures prescribed by the Non-Affiliated Soil Analysis Work Committee (1990).

\section{Data analysis}

Floristic analysis was conducted on the four mountain ranges within the refined borders of GWC. Plant lists were compiled for each mountain system based on historical distribution records that were obtained from herbarium specimens and combined with collected field data. A total 
of 44 field-collected plant specimens that could not be identified below genus level, were excluded from plant lists. Combined historical and field-collected data in the $1 \mathrm{~m}^{2}$ sub-plots were used to identify the 20 largest plant families of each mountain which were furthermore ranked based on the number of species. Spearman's rank correlation coefficient tests were performed in Statistica version 13.3 (TIBCO 2017) to assess similarity of plant family rankings between mountains. This correlation analysis followed a pairwise comparison between mountain combinations and Spearman's rho $(\rho)$, ranging from -1 and 1 (Schober et al. 2018), and was calculated for each pairwise rank. Significance was determined at $\mathrm{p}<0.05$. Jaccard similarity coefficients were performed on presence or absence of collected species data within $1 \mathrm{~m}^{2}$ sub-plots using PAST (Hammer et al. 2001). This analysis was conducted to establish the degree of similarity between sampled mountain systems based on presence/absence of herbaceous species. Plant species sampled in sub-plots of the Modified-Whittaker plots were ranked based on their overall abundances to reveal common plant species. NMDS scatter plot of $1 \mathrm{~m}^{2}$ field collected data, using the BrayCurtis dissimilarity distance measure, was constructed in Primer 6 (2012) to compare herbaceous species composition of mountain ecosystems. To assess whether clustering in the NMDS was significant, Non-parametric PERMANOVA analysis was conducted in Primer 6 (2012). Furthermore, indicator species analysis was performed in RStudio using the IndVal function under the labdsv package (Roberts 2016) and significance levels were set at $\mathrm{p}<0.05$. To correlate abundance of collected indicator plant species within sub-plots with environmental variables, CCA was performed in Canoco 5 (Šmilauer and Lepš 2014).

\section{RESULTS AND DISCUSSION}

\section{Refined borders of GWC}

The niche model had an average AUC of 0.979 for the 100 replicate runs, suggesting high model performance and a very good prediction (Phillips et al. 2006). Bioclimatic variables that showed the highest model contribution included temperature seasonality (annual range in temperature), precipitation seasonality (annual range in precipitation) and precipitation of the driest quarter (Table 2). This model output was overlaid onto the geology that is known to harbor GWC endemics and the core area boundary proposed by Frisby et al. (2019). The refined area (Figure 2), where all three layers overlap, is strongly associated with mountainous habitats with their associated unique geology and cooler climate, implying that endemic plant species are absent from the warmer, sand-filled valleys. Thus, the mountains of GWC are identified as hotspots within the centre of endemism due to topographic heterogeneity, geology and climate (Cañadas et al. 2014; Noroozi et al. 2018; Tordoni et al. 2020). The newly refined boundaries of GWC covers $24075 \mathrm{~km}^{2}$, a surface area three times smaller than the core area of $75172 \mathrm{~km}^{2}$ as proposed by Frisby et al. (2019). The refined boundaries of GWC are thus identified as conservation priority and emphasize the need to focus on a finer scale when defining centres of plant endemism. Focusing conservation efforts on the endemic rich mountains will ensure that rare species are protected (Noroozi et al. 2018). However, a systematic conservation approach (Margules and Pressey 2000) and development of conservation plans are required (Tordoni et al. 2020), since identified hotspots of endemism within GWC lie outside the borders of established protected areas, i.e. Mokala National Park, Witsand Nature Reserve, and Tswalu Kalahari Reserve.

Table 2. Estimates of the relative contributions of bioclimatic variables (BIO) to the MaxEnt model for GWC endemics. Values shown are averages of 100 replicate runs.

\begin{tabular}{lr}
\hline Variable & Percent contribution (\%) \\
\hline BIO1 = Annual Mean Temperature & 0.2 \\
BIO2 = Mean Diurnal Range (Mean of monthly (max temp - min temp)) & 1 \\
BIO3 = Isothermality (BIO2/BIO7) (*100) & 0 \\
BIO4 = Temperature Seasonality (standard deviation *100) & 37.2 \\
BIO5 = Max Temperature of Warmest Month & 0.4 \\
BIO6 = Min Temperature of Coldest Month & 0.4 \\
BIO7 = Temperature Annual Range (BIO5-BIO6) & 2.4 \\
BIO8 = Mean Temperature of Wettest Quarter & 0.5 \\
BIO9 = Mean Temperature of Driest Quarter & 0.2 \\
BIO10 = Mean Temperature of Warmest Quarter & 0 \\
BIO11 = Mean Temperature of Coldest Quarter & 0.1 \\
BIO12 = Annual Precipitation & 5.5 \\
BIO13 = Precipitation of Wettest Month & 0.1 \\
BIO14 = Precipitation of Driest Month & 1.6 \\
BIO15 = Precipitation Seasonality (Coefficient of Variation) & 27.8 \\
BIO16 = Precipitation of Wettest Quarter & 0.1 \\
BIO17 = Precipitation of Driest Quarter & 21.4 \\
BIO18 = Precipitation of Warmest Quarter & 1.3 \\
BIO19 = Precipitation of Coldest Quarter & 0 \\
\hline
\end{tabular}



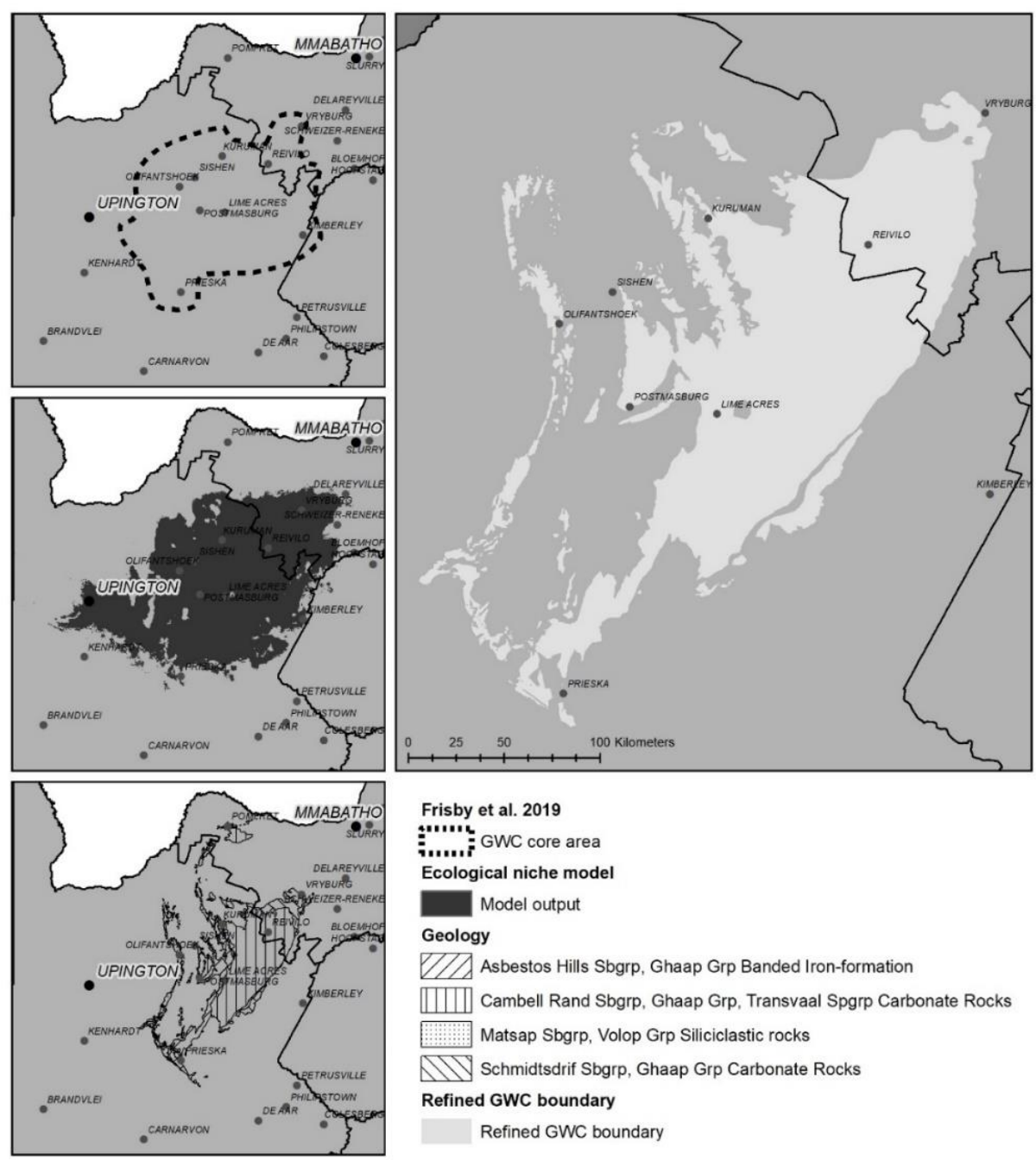

Figure 2. Refined GWC borders as predicted by overlays of the ecological niche model for endemic plant species with the core area defined by Frisby et al. (2019) and rock types known to harbor GWC endemics

\section{Soil characteristics}

$\mathrm{Ca}$ content exceeded $11000 \mathrm{mg} / \mathrm{kg}$ on the Ghaap Plateau, whilst $\mathrm{Mg}$ reached levels above $5000 \mathrm{mg} / \mathrm{kg}$ (Table 3). Consequently, the Ca: $\mathrm{Mg}$ ratio was above 2 and the soil $\mathrm{pH}>7$. These soil chemical properties of dolomite and limestone soil are supported by Lee (1999). Iron (Fe) levels were high $(>50000 \mathrm{mg} / \mathrm{kg})$ on banded ironstone Asbestos- and Kuruman Hills (Table 3 ) due to presence of hematite $\left(\mathrm{Fe}_{2} \mathrm{O}_{3}\right)$ and magnetite $\left(\mathrm{Fe}_{3} \mathrm{O}_{4}\right)$ (Trendall 2013). $\mathrm{Ca}: \mathrm{Mg}$ ratios were high due to lower concentrations of $\mathrm{Mg}$ $(<3000 \mathrm{mg} / \mathrm{kg})$ and higher $\mathrm{Ca}$ content $(>3000 \mathrm{mg} / \mathrm{kg})$. Furthermore, the two banded ironstone habitats were characterized by more acidic soils $(\mathrm{pH}<7)$ (Thompson and Sheehy 2011). This suggests that that banded ironstone differs from acidic serpentine soils that are usually associated with higher concentrations of $\mathrm{Mg}$ than $\mathrm{Ca}$ (Robinson et al. 1996; Alexander 2011). Aluminum (Al) levels exceeded $30000 \mathrm{mg} / \mathrm{kg}$ on the Langberg and Asbestos Hills (Table 3). Despite Al being one of the most abundant metals in soils, the availability thereof to plants is dependent on low soil pH (Gupta et al. 2013; Bojórquez-
Quintal et al. 2017). When soil acidity increases, Al can become available to plants and inhibit plant growth (Abedi et al. 2013; Bojórquez-Quintal et al. 2017). However, Al may be beneficial to certain taxa or contribute to the development of tolerance mechanisms in plants (Bojórquez-Quintal et al. 2017). In addition, Al levels act as an environmental filter (Abedi et al. 2013) that contribute to compositional and structural changes in plant communities (Mota et al. 2018). Acid and sandy soils, especially those associated with quartzite, are known to be rich in Al, low in clay content and all of potassium (K), sodium $(\mathrm{Na}), \mathrm{Mg}$ and $\mathrm{Ca}$, and, hence, considered nutrientpoor (Negreiros et al. 2014; Do Carmo and Jacobi 2016). EC, an indicator of soil fertility (Fourie 2019), for the dry Langberg and Asbestos Hills, was below $23 \mathrm{Ms} / \mathrm{m}$ and indicating lower fertility (Table 3). In contrast, EC values were higher $(>30 \mathrm{Ms} / \mathrm{m})$ for the Kuruman Hills and Ghaap Plateau. A soil fertility gradient, together with a rainfall gradient, could thus be observed for GWC as indicated by the dendrogram of Jaccard Similarity based on sampled species (Figure 3). 
Table 3. Mean concentrations with standard deviation of four elements and physical properties of soils associated with each mountain $(\mathrm{n}=8)$. LB=Langberg; AH=Asbestos Hills; KH=Kuruman Hills; GP=Ghaap Plateau.

\begin{tabular}{|c|c|c|c|c|c|c|c|c|}
\hline & $\mathrm{Ca}$ (mg/kg) & Mg (mg/kg) & $\mathrm{Fe}(\mathrm{mg} / \mathrm{kg})$ & Al (mg/kg) & Ca: Mg & pH & $\begin{array}{c}\text { EC } \\
(\mathrm{Ms} / \mathrm{m})\end{array}$ & $\begin{array}{c}\mathrm{CEC} \\
\mathrm{cmol}(+) / \mathrm{kg}\end{array}$ \\
\hline LB & $1347 \pm 921$ & $2643 \pm 664$ & $13741 \pm 1279$ & $33868 \pm 3568$ & $0.5 \pm 0.6$ & $4.9 \pm 0.4$ & $19.3 \pm 11.2$ & $14.9 \pm 1.3$ \\
\hline $\mathrm{AH}$ & $4040 \pm 1237$ & $3320 \pm 651$ & $52437 \pm 10021$ & $36318 \pm 4703$ & $1.2 \pm 0.3$ & $6.0 \pm 0.3$ & $22.4 \pm 11.9$ & $19.1 \pm 2.2$ \\
\hline $\mathrm{KH}$ & $3126 \pm 2573$ & $2946 \pm 438$ & $61660 \pm 19585$ & $27055 \pm 5043$ & $1.1 \pm 0.8$ & $5.5 \pm 0.3$ & $31.8 \pm 20.2$ & $20.6 \pm 2.7$ \\
\hline GP & $11844 \pm 9241$ & $5296 \pm 2790$ & $18876+4721$ & $30142 \pm 6981$ & $2.2 \pm 3.2$ & $7.6 \pm 0.6$ & $32.6 \pm 14.2$ & $20.2 \pm 3.1$ \\
\hline
\end{tabular}

Table 4. Comparison of field-collected (Field) data with historical herbarium records (Hist.) regarding taxa numbers represented in the flora of each mountain ecosystem of GWC. Unique species are those plant species that are not shared between mountain ranges.

\begin{tabular}{lcccccccc}
\hline & \multicolumn{2}{c}{ Langberg } & \multicolumn{2}{c}{ Asbestos hills } & \multicolumn{2}{c}{ Kuruman hills } & \multicolumn{2}{c}{ Ghaap plateau } \\
\cline { 2 - 8 } & Hist. & Field & Hist. & Field & Hist. & Field & Hist. & Field \\
\hline Families & 65 & 39 & 75 & 40 & 83 & 38 & 73 & 45 \\
Genera & 192 & 89 & 252 & 93 & 287 & 89 & 223 & 94 \\
Species & 325 & 126 & 472 & 114 & 551 & 114 & 410 & 134 \\
Species: Genus & 1.69 & 1.42 & 1.87 & 1.23 & 1.92 & 1.28 & 1.84 & 1.43 \\
Species/Family & 5 & 3.23 & 6.29 & 2.85 & 6.64 & 3 & 5.62 & 2.98 \\
N Unique Species & 102 & 35 & 112 & 14 & 152 & 30 & 103 & 43 \\
\% Unique Species & 31.38 & 27.78 & 23.73 & 12.28 & 27.59 & 26.32 & 25.12 & 32.09 \\
\hline
\end{tabular}

\section{Flora of GWC's mountain ecosystems \\ Sampling effort}

A plant list of historical data records was compiled for each mountain system within GWC. As would be expected, historical data indicated higher taxa numbers than field data (based on eight Modified-Whittaker plots per system; Table 4). Restricted sampling effort resulted in certain taxa not being found (Spyreas 2016). However, each mountain flora was associated with unique plant species. These species were restricted to specific habitats and can be considered habitat specialists within GWC (Anderson and Ferree 2010; Williamson and Balkwill 2015). Comparing field data with historical data revealed that unique species of the Asbestos Hills were more restricted in distribution and difficult to locate, despite a comparable number of overall species recorded. The opposite was observed for the Ghaap Plateau with unique species seemingly widespread and easily recorded. The latest discovery of a new endemic plant species Deverra rapaletsa Magee \& Zietsman, restricted to the Ghaap Plateau (Van Munster et al. 2019), emphasizes the unique flora of the Ghaap Plateau and the possibility of more species that are yet to be discovered. Floristic sampling on the Asbestos Hills was hampered due to poor rangeland conditions (overgrazing), which possibly favored common species tolerant to disturbance (Table 4). In contrast, sampling success for edaphic specialists was greater on the banded ironstone of the Kuruman Hills where the rangelands were managed responsibly.

\section{Dominant plant families}

Combined historical and field data revealed that the four most species-rich families across the four mountain landscapes were the Poaceae, Asteraceae, Fabaceae and Malvaceae in descending order (See supplementary, Table A4). These plant families are known to be of the largest and most widespread families, not only in southern Africa, but on a global scale. Members of these four families are known to occupy a variety of habitats and persist under various environmental conditions (Koekemoer et al. 2014). More specifically, the Asteraceae, Fabaceae, and Poaceae have been found to dominate plant communities on limestone and dolomite (Ludwig 1999; Siebert and Siebert 2005), banded ironstone (Jacobi and Do Carmo 2008; Markey and Dillon 2010; Gibson et al. 2012), as well as quartzite (Curtis et al. 2013; Neri et al. 2019). Since GWC is situated in the Savanna Biome, the representation by members of the Malvaceae can be ascribed to their preferred association and diversification in savanna landscapes (Koekemoer et al. 2014; Soares et al. 2015). The joined fifth most species-rich plant families in GWC, i.e. Cyperaceae and Scrophulariaceae, is respectively associated either with the lower rainfall (Langberg and Asbestos Hills) or higher rainfall mountains (Kuruman Hills and Ghaap Plateau). The Scrophulariaceae is widely distributed globally and is common in drier, open savannagrasslands, as well as mountainous areas (Fischer 2004; Koekemoer et al. 2014). Furthermore, some taxa are habitat specialists since they prefer rocky and dry granitic outcrops and/or ferricretes and, hence are often drought tolerant (Clements et al. 2002; Fischer 2004; Koekemoer et al. 2014). Many Scrophulariaceae have also been found to be metallophytes and, hence able to tolerate heavy metals in soils especially copper $(\mathrm{Cu})$ and cobalt $(\mathrm{Co})$ in southcentral Africa (Faucon et al. 2009). In contrast, the Cyperaceae is mostly found in moister habitats in savannagrassland regions (Koekemoer et al. 2014). Since the Ghaap Plateau is underlain by dolomite and limestone, soils tend to be rich in lime $(\mathrm{CaO})$, alkaline, high in clay content and poorly drained (Mustart et al. 1994). This provides a suitable habitat for taxa in the Cyperaceae. Ludwig (1999), as well as Swadek and Burgess (2012), conducted studies on North American limestones and found that the Cyperaceae was respectively the fourth and fifth most diverse plant family. Both studies recorded 17 
taxa within the Cyperaceae, a number that corresponds to the number of taxa present on the Ghaap Plateau (See supplementary, Table A4). The Kuruman Hills and Ghaap Plateau are rocky habitats. Consequently, presence of rock crevices, drainage lines and shallow depressions where rainwater can collect, serves as microhabitats for the Cyperaceae to establish successfully (Porembski and Barthlott 2000; Jacobi and Do Carmo 2008).

\section{Diversity on family- and species level}

Most diverse families of the Asbestos Hills correlated significantly with the most diverse families of the Kuruman Hills (Table 5; $\rho=0.88 ; \mathrm{p}<0.05$ ). Jaccard similarity, based on sampled plant species (Table 6), also revealed highest similarity between these two mountain landscapes $(38 \%)$. Similarities between the Kuruman- and Asbestos Hills could be ascribed to the fact that both these mountains are characterized by banded ironstone (Van Wyk and Smith 2001) and the same vegetation type, namely the Kuruman Mountain Bushveld (Mucina and Rutherford 2006). Dendrograms of Spearman correlation (See supplementary, Figure B1) and Jaccard similarity (Figure 3) indicated that the floristic difference between the two banded ironstone habitats is most likely attributed to rainfall, since the Kuruman Hills receives higher rainfall than the southern lying Asbestos Hills (Table 1).

The Langberg family diversity was moderately correlated (Table 5) with the Asbestos Hills $(\rho=0.77$; $\mathrm{p}<0.05)$, and the least with the Ghaap Plateau $(\rho=0.56$; $\mathrm{p}<0.05)$. This is likely attributed to differences in $\mathrm{pH}$ values (low vs. high) since the Langberg has acidic soils and the Ghaap Plateau is alkaline (Table 3). Jaccard similarity indicated that the Asbestos Hills and Langberg share $34 \%$ of their species (Table 6), despite differences in geology. Both these landscapes are characterized by lower rainfall (Table 1), suggesting a shared drought-tolerant and/or resistant flora (Kimball et al. 2017).

The Kuruman Hills and Ghaap Plateau mountain systems revealed similar family diversity (Table $5 ; \rho=0.72$; $\mathrm{p}<0.05)$. This finding could be attributed to the higher rainfall regime associated with these two systems within GW (Table 1). Therefore, the most species-rich plant families shared in high abundances, such as Cyperaceae, are adapted to these moister systems (See supplementary, Table A4). However, on species level, the Ghaap Plateau and Kuruman Hills had the lowest Jaccard similarity (Table $6 ; 22 \%$ ) which indicates differing species-specific colonization on contrasting geological substrates. Spearman correlation (Table 5) revealed that the Ghaap Plateau and Asbestos Hills were also similar in their most diverse plant families $(\rho=0.70 ; \mathrm{p}<0.05)$, but even more so at species level (Table 6, 34.6\%). This was unexpected since these systems differ in geology and rainfall regimes. The only meaningful explanation would be that the Ghaap Plateau and Asbestos Hills are in close proximity to one another (less than $50 \mathrm{~km}$ ). Therefore, plant species may easily migrate between the two systems especially when species have wide niche breadths and are generalist plant species (Sklenáŕ et al. 2014; Zhang et al. 2016).

\section{Species composition}

NMDS analysis of floristic sub-plot data revealed clustering according to mountain ecosystems (Figure 4). PERMANOVA analysis revealed that the clustering was significant (See supplementary, Table A5; Pseudo$\mathrm{F}=9.138 ; \mathrm{p}<0.001)$. Although Langberg plots were dispersed without a clear cluster, herbaceous assemblages differed significantly between mountains (See supplementary, Table A5). These findings are in accordance with studies which have found that plant communities underlay by banded ironstone (Jacobi et al. 2007; Gibson et al. 2012), dolomite and limestone (Siebert and Siebert 2005; Zietsman and Bredenkamp 2007; Mota et al. 2008) and quartzites (Wild et al. 1963; Schmiedel and Jürgens 2004) are distinct. In semi-arid savannas, soil nutrients and rainfall are of the most important factors determining vegetation dynamics, especially for the herbaceous layer (Siebert and Dreber 2019). Despite similar geologies, the separate clustering displayed by the Kuruman Hills and Asbestos Hills emphasizes the important role of rainfall in driving compositional differences, since both have the same rock type, but the latter is a drier system.

Each mountain system was characterized by certain commonly occurring species (See supplementary, Table A6) as indicated by the top 20 highest ranked taxa based on abundance values per se. Despite certain of these taxa being shared between different mountain systems, their relative frequency differed per system. For example, Eragrostis nindensis Ficalho \& Hiern was shared between the Langberg, Asbestos Hills and Kuruman Hills, yet this grass species had the highest abundance values on the Langberg (See supplementary, Table A6). Indicator plant species (Table 7) are characterized by high relative frequency of occurrence in a specific mountain habitat (specificity) and thus were primarily found in that habitat in high numbers (Dufrêne and Legendre 1997). In contrast to common species, indicator plant species provide valuable ecological information on various species groups of different plant communities (Dufrêne and Legendre 1997), especially with respect to their habitat preferences and adaptations to persist under certain environmental conditions (Siebert et al. 2010).

The effects of rainfall and soil properties on indicator plant species were confirmed by CCA analysis (Figure 5). Explanatory variables accounted for $47.7 \%$ of the total variation. The first canonical axis explained $70.3 \%$ of total variation and the second axis $41 \%$ of the variance. The Ghaap Plateau was positively correlated with $\mathrm{Ca}: \mathrm{Mg}$ ratio, soil $\mathrm{pH}$ and negatively correlated with Fe content (Figure 5), with a clear separation between the plots of the Ghaap Plateau and banded ironstone hills. Thus, indicator plant species of the Ghaap Plateau preferred alkaline soil with high $\mathrm{Ca}: \mathrm{Mg}$ ratios. In contrast, those of the Kuruman Hills are adapted to more acidic soils with high Fe content. A study conducted by Li et al. (2015) in subtropical China, revealed separation of indicator plant species across a $\mathrm{pH}$ gradient in combination with other environmental variables. Therefore, soil chemical characteristics can be considered as one of the most significant factors driving 
floristic composition across mountain ecosystems (Boneschans et al. 2015) and explain the preferences of indicator plant species associated with each mountain (Soares et al. 2015).

The Langberg was positively correlated with higher soil sand content. The Ghaap Plateau, as well as Kuruman Hills, were positively correlated with MAP and CEC (Figure 5). Indicator plant species of the Langberg, with its low MAP, high sand content and low CEC values, were separated clearly from other wetter and more nutrient-rich mountain systems (Figure 5). Plots of the Asbestos Hills were clustered intermediately between those of the Ghaap Plateau and Kuruman Hills. There is thus evidence of niche partitioning (Naaf and Wulf 2012) and a filtering effect (Franklin et al. 2013) for herbaceous indicator plant species across the nutrient- and rainfall gradient. The two drier and nutrient-poor systems (Langberg and Asbestos Hills) were predominantly characterized by perennial species of only two life form types (dwarf shrubs and grasses; Table 7). In contrast, the regions of higher rainfall and nutrients (Kuruman Hills and Ghaap Plateau), consisted of both perennial and annual indicator plant species comprising four life form types (dwarf shrubs, forbs, grasses, and sedges; Table 7).

Table 5. Spearman rank correlation $(\rho)$ test of the highest-ranked and most diverse plant families. All correlations were significant $(\mathrm{p}<0.05) . * *$ highest correlation; * lowest correlation.

\begin{tabular}{llll}
\hline & $\begin{array}{l}\text { Asbestos } \\
\text { Hills }\end{array}$ & Langberg & $\begin{array}{l}\text { Kuruman } \\
\text { Hills }\end{array}$ \\
\hline Langberg & 0.77 & & \\
Kuruman Hills & $0.88^{* *}$ & 0.66 & \\
Ghaap Plateau & 0.70 & $0.56^{*}$ & 0.72 \\
\hline
\end{tabular}

Table 6. Jaccard similarity coefficient measuring the degree of similarity of plant species between sampled mountain systems. Values are expressed as percentages. ** highest similarity; * lowest similarity.

\begin{tabular}{llll}
\hline & Langberg & $\begin{array}{l}\text { Kuruman } \\
\text { Hills }\end{array}$ & $\begin{array}{l}\text { Asbestos } \\
\text { Hills }\end{array}$ \\
\hline Kuruman Hills & 31.2 & - & \\
Asbestos Hills & 34.4 & $38.2^{* *}$ & - \\
Ghaap Plateau & 24.3 & $21.7^{*}$ & 34.6 \\
\hline
\end{tabular}

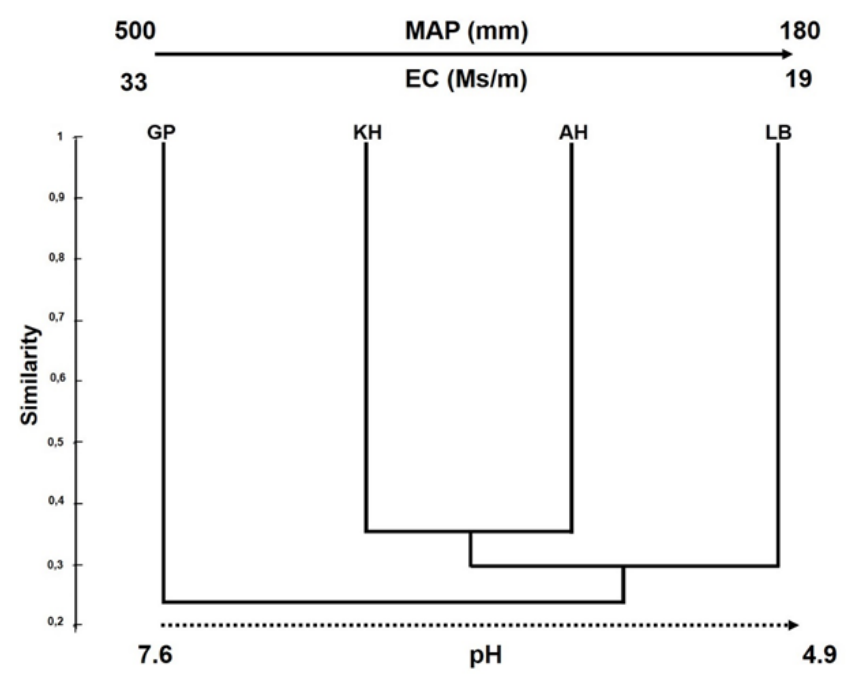

Figure 3. Dendrogram of Jaccard Similarity indicating the relatedness of each mountain ecosystem across the $\mathrm{pH}-$, nutrientand rainfall gradient. Clusters were based on presence and absence of sampled plant species.

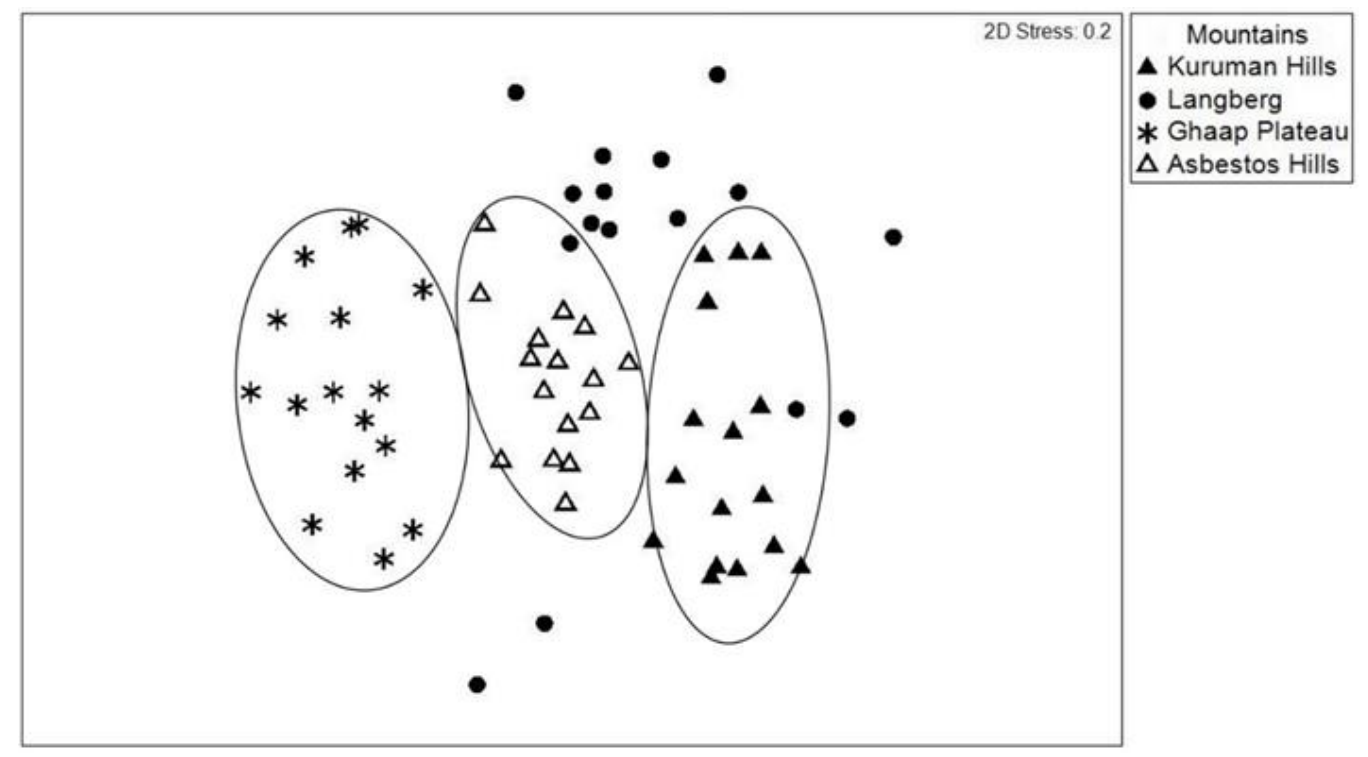

Figure 4. NMDS ordination of sampled sub-plots representing herbaceous species assemblages of the four mountain ecosystems. 
Despite this study not following a trait-based approach, the larger variety of life forms and life history characteristics of indicator species associated with the Kuruman Hills and Ghaap Plateau, suggests that niches increase along a soil fertility and precipitation gradient (Schellenberger Costa et al. 2017). Since indicator species of wetter and more nutrient-rich habitats have more traits (i.e., different life forms and life histories), it can be ascribed to niche partitioning (Naaf and Wulf 2012). In contrast, nutrient-poor and drier mountains have indicator plant species with fewer traits (Wright et al. 2002; Shovon et al. 2020). Therefore, reduction of trait richness of indicator plant species in the drier Langberg and Asbestos Hills are ascribed to environmental filtering. Thus, these dominant traits provide species with competitive vigor and stress tolerance to persist in the associated extreme environmental conditions (Negreiros et al. 2014). This suggests habitat specialization of indicator plant species $(\mathrm{Li}$ et al. 2015).

Table 7. List of indicator plant species associated with each mountain as determined by indicator species analysis (Indval function of the labdsv package in RStudio).

\begin{tabular}{|c|c|c|c|c|c|c|c|}
\hline Mountain & Family & Species & Indval & p-value & Frequency & Life history & Life form \\
\hline \multicolumn{8}{|l|}{ Langberg } \\
\hline & Poaceae & Brachiaria nigropedata & 0.48 & 0.001 & 13 & Perennial & Grass \\
\hline & Convolvulaceae & Evolvulus alsinoides & 0.44 & 0.001 & 7 & Perennial & Dwarf shrub \\
\hline & Poaceae & Eragrostis nindensis & 0.32 & 0.019 & 14 & Perennial & Grass \\
\hline & Poaceae & Eragrostis chloromelas & 0.2 & 0.037 & 6 & Perennial & Grass \\
\hline \multicolumn{8}{|c|}{ Asbestos Hills } \\
\hline & Acanthaceae & Glossochilus burchellii & 0.69 & 0.001 & 11 & Perennial & Dwarf shrub \\
\hline & Poaceae & Tragus koelerioides & 0.59 & 0.001 & 21 & Perennial & Grass \\
\hline & Poaceae & Aristida diffusa & 0.57 & 0.001 & 32 & Perennial & Grass \\
\hline & Poaceae & Cymbopogon pospischilii & 0.54 & 0.001 & 28 & Perennial & Grass \\
\hline & Verbenaceae & Chascanum pinnatifidum & 0.35 & 0.003 & 15 & Perennial & Dwarf shrub \\
\hline & Malvaceae & Sida chrysantha & 0.32 & 0.007 & 11 & Perennial & Dwarf shrub \\
\hline & Malvaceae & Corchorus aspelinifolius & 0.25 & 0.034 & 12 & Perennial & Forb \\
\hline & Lamiaceaae & Leucas capensis & 0.21 & 0.028 & 5 & Perennial & Dwarf shrub \\
\hline \multicolumn{8}{|c|}{ Kuruman Hills } \\
\hline & Poaceae & Diheteropogon amplectens & 0.81 & 0.001 & 13 & Perennial & Grass \\
\hline & Cyperaceae & Bulbostylis hispidula & 0.67 & 0,001 & 15 & Annual & Sedge \\
\hline & Poaceae & Cymbopogon caesius & 0.5 & 0.002 & 8 & Perennial & Grass \\
\hline & Euphorbiaceae & Phyllanthus parvulus & 0.46 & 0.002 & 35 & Perennial & Dwarf shrub \\
\hline & Poaceae & Brachiaria serrata & 0.45 & 0.001 & 14 & Perennial & Grass \\
\hline & Poaceae & Elionurus muticus & 0.44 & 0.001 & 10 & Perennial & Grass \\
\hline & Asteraceae & Pegolettia retrofracta & 0.32 & 0.003 & 7 & Perennial & Dwarf shrub \\
\hline & Verbenaceae & Chascanuma denostachyum & 0.31 & 0.005 & 5 & Perennial & Dwarf shrub \\
\hline & Poaceae & Anthephora pubescens & 0.31 & 0.008 & 17 & Perennial & Grass \\
\hline & Ebenaceae & Euclea undulata & 0.19 & 0.046 & 3 & Perennial & Dwarf shrub \\
\hline & Polygalaceae & Polygala hottentotta & 0.19 & 0.048 & 3 & Perennial & Dwarf shrub \\
\hline \multicolumn{8}{|c|}{ Ghaap Plateau } \\
\hline & Cyperaceae & Bulbostylis humilis & 0.3 & 0.001 & 25 & Annual & Sedge \\
\hline & Poaceae & Enneapogon desvauxii & 0.69 & 0.001 & 11 & Perennial & Grass \\
\hline & Poaceae & Fingerhuthia africana & 0.5 & 0.001 & 18 & Perennial & Grass \\
\hline & Oxalidaceae & Oxalis depressa & 0.44 & 0.001 & 7 & Perennial & Forb \\
\hline & Poaceae & Tragus racemosa & 0.44 & 0.001 & 7 & Annual & Grass \\
\hline & Euphorbiaceae & Euphorbia inaequilatera & 0.42 & 0.002 & 14 & Perennial & Forb \\
\hline & Molluginaceae & Limeum fenestratum & 0.38 & 0.002 & 6 & Annual & Dwarf shrub \\
\hline & Molluginaceae & Limeum argute-carinatum & 0.34 & 0.003 & 7 & Annual & Dwarf shrub \\
\hline & Poaceae & Eragrostis lehmanniana & 0.33 & 0.019 & 23 & Perennial & Grass \\
\hline & Cyperaceae & Cyperus bellus & 0.31 & 0.002 & 5 & Perennial & Forb \\
\hline & Poaceae & Oropetium capense & 0.25 & 0.008 & 4 & Perennial & Grass \\
\hline & Poaceae & Eragrostis trichophora & 0.24 & 0.019 & 8 & Perennial & Grass \\
\hline & Poaceae & Enneapogon scoparius & 0.19 & 0.045 & 3 & Perennial & Grass \\
\hline
\end{tabular}




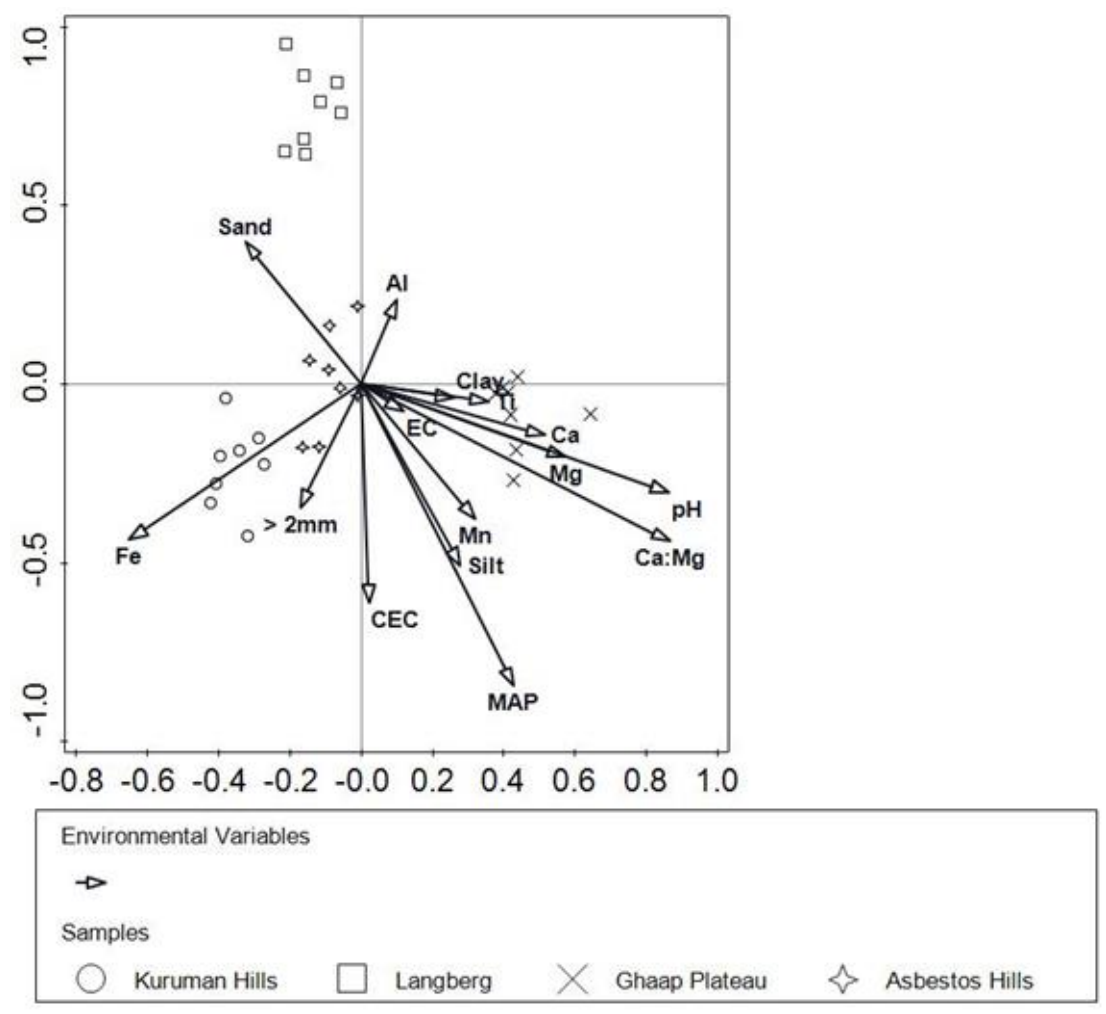

Figure 5. CCA biplot of indicator plant species per plot and associated environmental variables within each mountain system. Species included in the analysis are listed in Table 7.

\section{Threatened and endemic species}

The Ghaap Plateau hosted the highest number of GWC endemic plant species followed by the ironstone hills (See supplementary, Table A7). These findings are in accordance with several studies which revealed that limestone and dolomite (Ludwig 1999; Zietsman and Bredenkamp 2007; Mota et al. 2008), as well as banded ironstone (Gibson et al. 2012; Robinson et al. 2019) harbor high numbers of endemics. Six GWC endemic plant species (See supplementary, Table A7) can be considered narrow endemics since they are restricted to a single mountain range (Wild et al. 1963). Three of these restricted endemics were associated with the Ghaap Plateau that included a recently added species, Nerine hesseoides L.Bolus (See supplementary, Table A8), after an outlying locality was confirmed to be a different species. Two other endemics were associated with seasonal pans of the Ghaap Plateau. The ironstone hills harbor one narrow endemic, while the Langberg with its deeper, sandy soils harbors two species. Therefore, these plant species show an edaphic preference (Mason 1946; Rajakaruna 2004) and can be considered as rare (Stebbins 1942; Gaston 1997). Edaphic restricted endemic plant species may be prone to extinction (Harrison et al. 2009) due to low genetic variability (Stebbins 1942). Despite low genetic diversity, narrow resource use abilities and narrowed niche range (Gaston and Kunin 1997), these plants are highly specialized and thus edaphic specialists (Mason 1946; Anderson and Ferree 2010).

Eleven of the $24 \mathrm{GWC}$ endemics were recorded during the field surveys. More commonly sampled endemics included Blepharis marginata (Nees) C.B.Clarke, Calobota cuspidosa (Burch.) Boatwr. \& B.-E.vanWyk, Glossochilus burchellii Nees, Searsia tridactyla (Burch.) Moffett and Tarchonanthus obovatus DC. (Table 8). These endemic plant species are also associated with a wider distribution range within GWC and can be considered regional endemics (Cowling et al. 1994) with wider ecological niches compared to narrow endemics (Gaston and Kunin 1997). The random sampling approach of this study did not allow the targeting of rare species with patchy distributions and strict habitat specificity (Stohlgren et al. 2005). It is suggested that future studies must determine optimal sampling effort, sampling time and plot size to ensure more comprehensive data capturing of endemic species in GWC, especially at landscape scale (Zhang et al. 2014). By doing so, conservation efforts of endemic plant species can be promoted since all 24 endemic plant species are of conservation concern, irrespective that none of the endemics are currently regarded as endangered (South African National Biodiversity Institute 2019). 
Table 8. List of GWC endemic plant species, number of individuals recorded during Modified-Whittaker plot surveys, mountains where it is known to occur, number herbarium QDG records and Red List category. AH-Asbestos Hills; GP-Ghaap Plateau; KH-Kuruman Hills; LB-Langberg.

\begin{tabular}{|c|c|c|c|c|c|}
\hline Family & Taxon & $\begin{array}{c}\text { Individuals } \\
\text { recorded }\end{array}$ & Mountains & $\begin{array}{c}\text { QDG } \\
\text { records }\end{array}$ & Category \\
\hline \multicolumn{6}{|l|}{ Acanthaceae } \\
\hline & Barleria media & - & $\mathrm{GP}, \mathrm{KH}$ & 4 & Vulnerable \\
\hline & Blepharis marginata & 51 & $\mathrm{AH}, \mathrm{GP}, \mathrm{KH}, \mathrm{LB}$ & 12 & Least concern \\
\hline & Glossochilus burchellii & 56 & $\mathrm{AH}, \mathrm{GP}, \mathrm{KH}$ & 10 & Least concern \\
\hline & Justicia puberula & 4 & GP, KH, LB & 30 & Least concern \\
\hline \multicolumn{6}{|l|}{ Aizoaceae } \\
\hline & Antimima lawsonii & - & $\mathrm{AH}, \mathrm{GP}, \mathrm{KH}$ & 5 & Rare \\
\hline & Hereroa wilmaniae & 3 & $\mathrm{AH}, \mathrm{GP}, \mathrm{KH}, \mathrm{LB}$ & 15 & Data deficient \\
\hline & Lithops aucampiae subsp. euniceae & - & $\mathrm{AH}$ & 2 & Vulnerable \\
\hline & Lithops bromfieldii & - & LB & 4 & Least concern \\
\hline & Lithops lesliei subsp. burchellii & - & $\mathrm{AH}, \mathrm{GP}$ & 3 & Near threatened \\
\hline & Prepodesma orpenii & - & $\mathrm{AH}, \mathrm{GP}, \mathrm{KH}, \mathrm{LB}$ & 23 & Least concern \\
\hline \multicolumn{6}{|l|}{ Amaryllidaceae } \\
\hline & Nerine hesseoides & - & GP & 4 & Least concern \\
\hline Anacardiaceae & Searsia tridactyla & 30 & AH, GP, KH, LB & 63 & Least concern \\
\hline \multicolumn{6}{|l|}{ Apiaceae } \\
\hline & Deverra rapaletsa & - & GP & 2 & Not yet assessed \\
\hline \multicolumn{6}{|l|}{ Asteraceae } \\
\hline & Amphiglossa tecta & 1 & AH, GP, LB & 3 & Critically Rare \\
\hline & Cineraria exilis & - & $\mathrm{GP}, \mathrm{KH}$ & 1 & Data deficient \\
\hline & Dicoma kurumanii & 4 & $\mathrm{GP}, \mathrm{KH}$ & 1 & Least concern \\
\hline & Eriocephalus ericoides subsp. griquensis & 17 & AH, GP, KH, LB & 26 & Least concern \\
\hline & Gnaphalium englerianum & - & $\mathrm{GP}, \mathrm{KH}$ & 2 & Least concern \\
\hline & Pentzia stellata & - & GP & 11 & Near threatened \\
\hline & Tarchonanthus obovatus & 40 & AH, GP, KH, LB & 53 & Least concern \\
\hline \multicolumn{6}{|l|}{ Celastraceae } \\
\hline & Maytenus ilicina & - & $\mathrm{AH}, \mathrm{GP}, \mathrm{KH}, \mathrm{LB}$ & 11 & Least concern \\
\hline & Putterlickia saxatilis & 3 & $\mathrm{AH}, \mathrm{GP}, \mathrm{KH}, \mathrm{LB}$ & 28 & Least concern \\
\hline \multicolumn{6}{|l|}{ Fabaceae } \\
\hline & Calobota cuspidosa & 23 & AH, GP, KH, LB & 45 & Least concern \\
\hline \multicolumn{6}{|l|}{ Poaceae } \\
\hline & Brachiaria dura var. pilosa & - & LB & 4 & Data deficient \\
\hline
\end{tabular}

Note: QDG's were obtained from BODATSA (Ranwashe 2019). Categories for threats were based on the National Red List (South African National Biodiversity Institute 2019).

In conclusion, this study refined the borders of GWC which enabled the floristic description of the four, endemic-rich mountain landscapes within these new borders. These borders were based on an ecological model, which was constructed using presence and absence records of GWC endemics and environmental parameters. Distribution patterns of endemics were restricted to certain mountain landscapes and geologies which allowed for refinement of the model.

A clear soil fertility and rainfall gradient was identified for the GWC and, subsequently, each mountain flora was associated with different family- and species diversity, and composition. All four mountain landscapes were dominated by the Asteraceae, Fabaceae Malvaceae and Poaceae. Furthermore, the Scrophulariaceae dominated on the mountains of lower rainfall that are nutrient-poor (Langberg and Asbestos Hills), whereas the Cyperaceae were prominent on the two mountain systems of higher rainfall and which are more nutrient rich (Kuruman Hills and Ghaap Plateau). Indicator plant species explained the compositional differences since each mountain ecosystem was characterized by habitat specialists adapted to prevailing edaphic and climatic conditions. Primary drivers of the distribution of indicator species were soil $\mathrm{pH}, \mathrm{Ca}$ : $\mathrm{Mg}$ ratios and rainfall. These drivers contributed to niche 
partitioning and environmental filtering (dry and nutrient poor $v s$. wet and nutrient rich).

From a conservation perspective, future botanical studies, and conservation and management strategies, should focus within the refined borders of GWC. The mountains are hotspots of endemics in GWC and should be considered as conservation priority areas. Especially the Ghaap Plateau and the ironstone hills since these systems harbour most of the GWC endemics. Special attention should be given to narrow endemic plant species with restricted distributions within GWC's borders as well as those species having a category of threat.

\section{ACKNOWLEDGEMENTS}

The first author would like to thank the landowners for providing access to their properties and for their warm welcome. Many thanks to everyone who assisted with fieldwork. Also, to Marié du Toit for her assistance with the maps and Ricart Boneschans for his help with XRF soil analysis. We thank the curators of various herbaria in central South Africa for providing access to their collections. Additional data were kindly provided by Proffs. Braam van Wyk, University of Pretoria, and Norbert Hahn, University of Venda. Analysis of the soil samples was conducted by the Eco Analytica Laboratory, North-West University. We also thank the SAWS for the provision of climate data. The financial assistance of the National Research Foundation (Grant UID: 103370), South Africa, as well as the Deutscher Akademischer Austauschdienst (DAAD) (Grant UID: 109741) towards this research is hereby acknowledged. Opinions expressed and conclusions arrived at, are those of the author and are not necessarily to be attributed to the NRF.

\section{REFERENCES}

Abedi M, Bartelheimer M, Poschlod P. 2013. Aluminium toxic effects on seedling root survival affect plant composition along soil reaction gradients-a case study in dry sandy grasslands. J Veg Sci 24: 10741085. DOI: $10.1111 /$ jvs. 12016

AGIS. 2007. Land Type Survey. http: //www.agis.agric.za/agisweb/?MIval=soils\&rb=broadsoil2

Alexander B. 2011. Serpentine soils and why they limit plant survival and growth. Fremontia 38/39: 28-31.

Anderson MG, Ferree CE. 2010. Conserving the stage: climate change and the geophysical underpinnings of species diversity. PLoS One 5: 1-10. DOI: 10.1371/journal.pone.0011554

Bean WT, Stafford R, Brashares JS. 2012. The effects of small sample size and sample bias on threshold selection and accuracy assessment of species distribution models. Ecography 35: 250-258. DOI: 10.1111/j.1600-0587.2011.06545.x

Bojórquez-Quintal E, Escalante-Magaña C, Echevarría-Machado I Martínez-Estévez M. 2017. Aluminum, a friend or foe of higher plants in acid soils. Front Plant Sci 8: 1767. DOI: 10.3389/fpls.2017.01767

Boneschans RB, Coetzee MS, Siebert SJ. 2015. A geobotanical investigation of the Koedoesfontein Complex, Vredefort Dome, South Africa. Aust J Bot 63: 324-340. DOI: 10.1071/BT14267

Callen ST, Miller AJ. 2015. Signatures of niche conservatism and niche shift in the North American kudzu (Pueraria montana) invasion. Divers Distrib 21: 853-863. DOI: 10.1111/ddi.12341

Cañadas EM, Fenu G, Peñas J, Lorite J, Mattana E, Bacchetta G. 2014 Hotspots within hotspots: Endemic plant richness, environmental drivers, and implications for conservation. Biol Conserv 170: 282291. DOI: 10.1016/j.biocon.2013.12.007

Chakraborty A. 2019. Mountains as vulnerable places: a global synthesis of changing mountain systems in the Anthropocene. GeoJournal: 120. DOI: 10.1007/s10708-10019-10079-10701.

Clements RK, Baskin JM, Baskin C. 2002. The comparative biology of the two closely-related species Penstemon tenuiflorus Pennell and $P$. hirsutus (L.) Willd. (Scrophulariaceae, Section Graciles): IV. Effects of shade, drought, and soil type on survival and growth. Castanea 67: 177-187.

Cowling RM, Witkowski ETF, Milewski AV, Newbey KR. 1994. Taxonomic, edaphic and biological aspects of narrow plant endemism on matched sites in mediterranean South Africa and Australia. J Biogeogr 21: 651-664. DOI: 10.2307/2846038

Curtis OE, Stirton CH, Muasya AM. 2013. A conservation and floristic assessment of poorly known species rich quartz-silcrete outcrops within Rûens Shale Renosterveld (Overberg, Western Cape), with taxonomic descriptions of five new species. S Afr J Bot 87: 99-111. DOI: 10.1016/j.sajb.2013.03.017

Do Carmo FF, Jacobi CM. 2016. Diversity and plant trait-soil relationships among rock outcrops in the Brazilian Atlantic rainforest. Plant Soil 403: 7-20. DOI: 10.1007/s11104-015-2735-7

Dufrêne M, Legendre P. 1997. Species assemblages and indicator species: the need for a flexible asymmetrical approach. Ecol Monogr 67: 345366. DOI: 10.1890/0012-9615(1997)067[0345: SAAIST]2.0.CO;2

Elith J, Phillips SJ, Hastie T, Dudík M, Chee YE, Yates CJ. 2011. A statistical explanation of MaxEnt for ecologists. Divers Distrib 17: 43-57. DOI: 10.1111/j.1472-4642.2010.00725.x

Eriksson PG, Altermann W, Hartzer FJ. 2006. The Transvaal Supergroup and its Precursors. In: Johnson MR. Anhauesser CR Thomas RJ. (eds) The Geology of South Africa. Geologocial Society/Council for Geoscience, Johannesburg/Pretoria.

Escalante T, Rodríguez-Tapia G, Linaje M, Illoldi-Rangel P, GonzálezLópez R. 2013. Identification of areas of endemism from species distribution models: threshold selection and Nearctic mammals. TIP Rev Esp Cienc Quim Biol 16: 5-17.

Faucon MP, Colinet G, Mahy G, Luhembwe MN, Verbruggen N, Meerts P. 2009. Soil influence on $\mathrm{Cu}$ and $\mathrm{Co}$ uptake and plant size in the cuprophytes Crepidorhopalon perennis and C. tenuis (Scrophulariaceae) in SC Africa. Plant Soil 317: 201-212.DOI: 10.1007/s11104-008-9801-3

Fick SE, Hijmans RJ. 2017. WorldClim 2: new 1-km spatial resolution climate surfaces for global land areas. Int J Climatol 37: 4302-4315. DOI: $10.1002 /$ joc.5086

Fischer E. 2004. Scrophulariaceae. In: Kubitzki K, Kadereit J. (eds) Flowering Plants - Dicotyledons: Lamiales The Families and Genera of Vascular Plants VII. Springer, Berlin.

Fourie M. 2019. What can electrical conductivity tell us about our soil? http: //traceandsave.com/what-can-electrical-conductivity-tell-usabout-our-

soil/\#targetText=One $\% 20$ of $\% 20$ the $\% 20$ insightful $\% 20$ measures,of $\% 2$ Onutrients\%20in\%20the\%20soil

Franklin J, Keppel G, Webb EL, Seamon JO, Rey SJ, Steadman DW, Wiser SK, Drake DR. 2013. Dispersal limitation, speciation, environmental filtering and niche differentiation influence forest tree communities in West Polynesia. J Biogeogr 40: 988-999. DOI: 10.1111/jbi.12038

Frisby AW, Siebert SJ, Struwig M, Cilliers DP. 2019. Plant endemism in Griqualand West, South Africa. S Afr J Bot 124: 127-137. DOI: 10.1016/j.sajb.2019.03.041

Gaston KJ. 1997. What is rarity? In: Kunin WE, Gaston KJ. (eds) The Biology of Rarity: Causes and consequences of rare-common differences. Vol. 17. Springer, London.

Gaston KJ, Kunin WE. 1997. Rare-common differences: An overview. In: Kunin WE, Gaston KJ. (eds) The Biology of Rarity: Causes and Consequences of Rare-Common Differences. Vol. 17. Springer, London.

Gibson N, Meissner R, Markey AS, Thompson WA. 2012. Patterns of plant diversity in ironstone ranges in arid south western Australia. J Arid Environ 77: 25-31. DOI: 10.1016/j.jaridenv.2011.08.021

Gupta N, Gaurav SS, Kumar A. 2013. Molecular basis of aluminium toxicity in plants: a review. Am J Plant Sci 4: 21-37. DOI: 10.4236/ajps.2013.412A3004

Hammer Ø, Harper DAT, Ryan PD. 2001. PAST: Paleontological Statistics software package for education and data analysis. Paleontol Electron 4. http: //paleo.electronica.org/2001_1/past/issue1_01.htm. 
Harrison S, Damschen E, Going BM. 2009. Climate gradients, climate change, and special edaphic floras. Northeast Nat 16: 121-130. DOI: $10.1656 / 045.016 .0510$

Jacobi CM, Do Carmo FF. 2008. The contribution of ironstone outcrops to plant diversity in the Iron Quadrangle, a threatened Brazilian landscape. Ambio 37: 324-327. DOI: 10.1579/0044 7447(2008)37[324: TCOIOT]2.0.CO;2

Jacobi CM, Do Carmo FF, Vincent RC, Stehmann JR. 2007. Plant communities on ironstone outcrops: a diverse and endangered Brazilian ecosystem. Biodivers Conserv 16: 2185-2200. DOI 10.1007/s10531-007-9156-8

Keyser N. 1997. Geological Map of the Republic of South Africa and the Kingdoms of Lesotho and Swaziland: Gravity Edition; 1: 1000000. Council for Geoscience, Pretoria.

Kimball SE, Lulow MR, Balazs K, Huxman TE. 2017. Predicting drought tolerance from slope aspect preference in restored plant communities. Ecol Evol 7: 3123-3131. DOI: 10.1002/ece3.2881

Koch J, Chakraborty S, Li B, Kucera JM, Van Deventer P, Daniell A Faul C, Man T, Pearson D, Duda B. 2017. Proximal sensor analysis of mine tailings in South Africa: An exploratory study. J Geochem Explor 181: 45-57. DOI: 10.1016/j.gexplo.2017.06.020

Koekemoer M, Steyn HM, Bester SP. 2014. Guide to plant families of southern Africa, edition 2. Strelitzia 31. South African National Biodiversity Institute, Pretoria.

Kruckeberg AR. 1969. Soil diversity and the distribution of plants, with examples from western North America. Madroño 20: 129-154.

Lee JA. 1999. The calcicole-calcifuge problem revisited. In: Callow JA (ed) Advances in Botanical Research Vol. 29. Academic Press, California.

Li J, Xiong G, Xu W, Xie Z. 2015. Distribution of shrublands in relation to soil and climate in mid-subtropical China. J Plant Ecol 9: 393401.DOI: $10.1093 /$ jpe/rtv070

Ludwig JC. 1999. The flora of dolomite and limestone barrens in southwestern Virginia. Castanea 64: 209-230.

Margules CR, Pressey RL. 2000. Systematic conservation planning Nature 405: 243-253. DOI: 10.1038/35012251

Markey AS, Dillon SJ. 2010. Flora and vegetation of the banded iron formations of the Yilgarn Craton: Gullewa. Conservation Science W Aust 7: 531-556.

Mason HL. 1946. The edaphic factor in narrow endemism. I. The nature of environmental influences. Madroño 8: 209-226.

McCarthy T, Rubidge B. 2005. The story of earth \& life: a southern Africa perspective on a 4.6 billion-year journey. Struik, Cape Town.

Millar TR, Heenan PB, Wilton AD, Smissen RD, Breitwieser I. 2017 Spatial distribution of species, genus and phylogenetic endemism in the vascular flora of New Zealand, and implications for conservation. Aust Syst Bot 30: 134-147. DOI: 10.1071/SB16015

Moen HFG. 2006. The Olifantshoek Supergroup. In: Johnson MR, Anhauesser CR, Thomas RJ. (eds) The Geology of South Africa. Geologocial Society /Council for Geoscience, Johannesburg/ Pretoria

Mostert JWC. 1967. Veld-tipes, -probleme en weidingnavorsing in die Oranje-Vrystaatstreek. Proceedings of the Annual Congresses of the Grassland Society of Southern Africa 2: 31-37. DOI 10.1080/00725560.1967.9648534

Mota GS, Luz GR, Mota NM, Coutinho ES, Veloso MDM, Fernande GW, Nunes YRF. 2018. Changes in species composition, vegetation structure, and life forms along an altitudinal gradient of rupestrian grasslands in south-eastern Brazil. Flora 238: 32-42. DOI: 10.1016/j.flora.2017.03.010

Mota JF, Medina-Cazorla JM, Navarro FB, Pérez-García FJ, PérezLatorre A, Sánchez-Gómez P, Torres JA, Benavente A, Blanca G, Gi C. 2008. Dolomite flora of the Baetic ranges glades (South Spain) Flora 203: 359-375. DOI: 10.1016/j.flora.2007.06.006

Mucina L, Rutherford MC. 2006. The vegetation of South Africa, Lesotho and Swaziland. Strelitzia 19. South African National Biodiversity Institute, Pretoria.

Mustart PJ, Cowling RM, Dunne TT. 1994. Reproductive traits of two closely related species-pairs on adjacent, different soil types in South African Fynbos. Vegetatio 111: 161-171. DOI: 10.1007/BF00040335

Naaf T, Wulf M. 2012. Plant community assembly in temperate forests along gradients of soil fertility and disturbance. Acta Oecol 39: 101108. DOI: $10.1016 /$ j.actao.2012.01.009

Negreiros D, Le Stradic S, Fernandes GW, Rennó HC. 2014. CSR analysis of plant functional types in highly diverse tropical grasslands of harsh environments. Plant Ecol 215: 379-388.
Neri AV, Silva WA, Villa PM, Schaefer CEGR. Ferreira-Júnior WG. 2019. Diversity and life-forms of a woody-herbaceous community on the quartzite rocky complexes in the Brazilian Iron Quadrangle. Rev Biol Trop 67: 357-369.

Non-Affiliated Soil Analysis Work Committee. 1990. Handbook of standard soil testing methods for advisory purposes Vol. 160. Soil Science Society of South Africa, Pretoria.

Noroozi J, Talebi A, Doostmohammadi M, Rumpf SB, Linder HP, Schneeweiss GM. 2018. Hotspots within a global biodiversity hotspot-areas of endemism are associated with high mountain ranges. Sci Rep 8: 10345. DOI: 10.1038/s41598-41018-28504-41599.

Peñas J, Pérez-García FJ, Mota JF. 2005. Patterns of endemic plants and biogeography of the Baetic high mountains (south Spain). Acta Bot Gallica 152: 347-360. DOI: 10.1080/12538078.2005.10515494

Phillips SJ, Anderson RP, Schapire RE. 2006. Maximum entropy modeling of species geographic distributions. Ecol Model 190: 231259.DOI: 10.1016/j.ecolmodel.2005.03.026

Phillips SJ, Dudík M, Elith J, Graham CH, Lehmann A, Leathwick J, Ferrier S. 2009. Sample selection bias and presence-only distribution models: implications for background and pseudo-absence data. Ecol Appl 19: 181-197. DOI: 10.1890/07-2153.1

Phillips SJ, Dudík M, Schapire RE. 2019. Maxent software for modeling species niches and distributions (Version 3.4.1). http: //biodiversityinformatics.amnh.org/open_source/maxent/

Porembski S, Barthlott W. 2000. Granitic and gneissic outcrops (inselbergs) as centers of diversity for desiccation-tolerant vascular plants. Plant Ecol 151: 19-28. DOI: 10.1023/A: 1026565817218

PRIMER 6 2012. Version 1.1.15. PRIMER-E Ltd.

Rajakaruna N. 2004. The edaphic factor in the origin of plant species. Int Geol Rev 46: 471-478. DOI: 10.2747/0020-6814.46.5.471

Rajakaruna N. 2018. Lessons on evolution from the study of edaphic specialization. Bot Rev 84: 39-78. DOI: 10.1007/s12229-017-9193-2

Ranwashe F. 2019. BODATSA: Botanical Collections. v1.4. South African National Biodiversity Institute. Dataset/Occurrence. http: //ipt.sanbi.org.za/iptsanbi/resource?r=brahms_online\&amp; $=1.4$

Roberts DW. 2016. Package 'labdsv'. ftp: //ftp.lab.unb.br/pub/plan/R/web/packages/labdsv/labdsv.pdf

Robinson BH, Brooks RR, Kirkman JH, Gregg PEH, Gremigni P. 1996. Plant-available elements in soils and their influence on the vegetation over ultramafic ("serpentine") rocks in New Zealand. J Roy Soc New Zeal 26: 457-468. DOI: doi.org/10.1080/03014223.1996.9517520

Robinson TP, Di Virgilio G, Temple-Smith D, Hesford J, WardellJohnson GW. 2019. Characterisation of range restriction amongst the rare flora of Banded Ironstone Formation ranges in semiarid southwestern Australia. Aust J Bot 67: 234-247. DOI: 10.1071/BT18111

Schellenberger Costa D, Gerschlauer F, Pabst H, Kühnel A, Huwe B, Kiese R, Kuzyakov Y, Kleyer M. 2017. Community-weighted means and functional dispersion of plant functional traits along environmental gradients on Mount Kilimanjaro. J Veg Sci 28: 684695. DOI: $10.1111 /$ jvs. 12542

Schmiedel U, Jürgens N. 1999. Community structure on unusual habitat islands: Quartz-fields in the Succulent Karoo, South Africa. Plant Ecol 142: 57-69. DOI: 10.1023/A: 1009818210799

Schmiedel U, Jürgens N. 2004. Habitat ecology of southern African quartz fields: studies on the thermal properties near the ground. Plant Ecol 170: 153-166. DOI: 10.1023/B: VEGE.0000021661.56381.67

Schober P, Boer C, Schwarte LA. 2018. Correlation coefficients: appropriate use and interpretation. Anesth Analg 126: 1763-1768. DOI: 10.1213/ANE.0000000000002864

Shovon TA, Rozendaal DM, Gagnon D, Gendron F, Vetter M, Vanderwel MC. 2020. Plant communities on nitrogen-rich soil are less sensitive to soil moisture than plant communities on nitrogen-poor soil. J Ecol 108: 133-144. DOI: 10.1111/1365-2745.13251

Siebert F, Siebert SJ. 2005. Dolomitic vegetation of the Sterkfontein Caves World Heritage Site and its importance in the conservation of Rocky Highveld Grassland. Koedoe 48: 17-31. DOI: 10.4102/koedoe.v48i1.163

Siebert F, Dreber N. 2019. Forb ecology research in dry savannas: knowledge, gaps and future perspectives. Ecol Evol 9: 7875-7891. DOI: $10.1002 /$ ece 3.5307

Siebert SJ, Van Wyk AE, Bredenkamp GJ. 2002. The physical environment and major vegetation types of Sekhukhuneland, South Africa. S Afr J Bot 68: 127-142. DOI: 10.1016/S02546299(15)30412-9

Siebert SJ, Retief E, Van Wyk AE, Struwig M. 2010. A new species of Polygala (Polygalaceae) from ultramafic soils in Sekhukhuneland, 
South Africa, with notes on its ecology. S Afr J Bot 76: 345-353. DOI: $10.1016 / j . s a j b .2010 .01 .003$

Sklenár P, Hedberg I, Cleef AM. 2014. Island biogeography of tropical alpine floras. J Biogeogr 41: 287-297. DOI: 10.1111/jbi.12212

Šmilauer P, Lepš J. 2014. Multivariate Analysis of Ecological Data using CANOCO 5. Cambridge University Press, Cambridge.

Soares MP, Reys P, Pifano DS, DeSá JL, Da Silva PO, Santos TM, Silva FG. 2015. Relationship between edaphic factors and vegetation in savannas of the Brazilian midwest region. Rev Bras Cienc Solo 39: 821-829. DOI: 10.1590/01000683rbcs20130726

South African National Biodiversity Institute. 2019. Red List of South African plants version 2017.1. http: //redlist.sanbi.org/index.php

Spyreas G. 2016. Scale and sampling effects on floristic quality. PloS One 11: e0160693. DOI: 10.1371/journal.pone.0160693

Stebbins GL. 1942. The genetic approach to problems of rare and endemic species. Madroño 6: 241-258.

Stohlgren TJ, Guenther DA, Evangelista PH, Alley N. 2005. Patterns of plant species richness, rarity, endemism, and uniqueness in an arid landscape. Ecol Appl 15: 715-725. DOI: 10.1890/03-5352

Swadek RK, Burgess TL. 2012. The vascular flora of the north central Texas Walnut Formation. J Bot Res Inst Texas 6: 725-752.

Taylor-Smith B, Morgan-Richards M, Trewick SA. 2020. Patterns of regional endemism among New Zealand invertebrates. N Z J Zool 47: 1-19. DOI: $10.1080 / 03014223.2019 .1681479$

Thompson WA, Sheehy NB. 2011. Flora and vegetation of banded iron formations of the Yilgarn Craton: the Montague Range Zone of the Gum Creek Greenstone Belt. Conserv Sci W Aust 8: 95-111.

TIBCO Software. 2017. Statistica (data analysis software system) version 13. http: //statistica.io.

Tordoni E, Casolo V, Bacaro G, Martini F, Rossi A, Boscutti F. 2020 Climate and landscape heterogeneity drive spatial pattern of endemic plant diversity within local hotspots in South-Eastern Alps. Perspect Plant Ecol 43: 125512. DOI: 10.1016/j.ppees.2020.125512

Trendall A. 2013. Sedimentary rocks: Banded Iron Formations. In: Elias SA (ed.) Reference Module in Earth Systems and Environmental Sciences. Elsevier, New York.
Van Munster S, Magee AR, Zietsman PC. 2019. Deverra rapaletsa (Apiaceae), a new limestone endemic species from the Ghaap Plateau, Northern Cape, South Africa. S Afr J Bot 121: 431-434. DOI: 10.1016/j.sajb.2018.12.005

Van Wyk AE, Smith GF. 2001. Regions of floristic endemism in southern Africa: A review with emphasis on succulents. Umdaus Press, Hatfield.

Wang SW, Boru BH, Njogu AW, Ochola AC, Hu GW, Zhou YD, Wang QF. 2020. Floristic composition and endemism pattern of vascular plants in Ethiopia and Eritrea. J Syst Evol 8: 33-42. DOI: $10.1111 /$ jse. 12527

Wild H, Brenan J, Meikle R, Peterson B, Cannon J. 1963. The endemic species of the Chimanimani mountains and their significance. Kirkia 4: 125-157.

Williamson S, Balkwill K. 2015. Plant census and floristic analysis of selected serpentine outcrops of the Barberton Greenstone Belt, Mpumalanga, South Africa. S Afr J Bot 97: 133-142. DOI: 10.1016/j.sajb.2014.12.004

Wilman M. 1946. Preliminary check list of the flowering plants \& ferns of Griqualand West (southern Africa). Deighton, Bell \& Co., Cambridge.

Wright IJ, Westoby M, Reich PB. 2002. Convergence towards higher leaf mass per area in dry and nutrient-poor habitats has different consequences for leaf life span. J Ecol 90: 534-543. DOI: 10.1046/j.1365-2745.2002.00689.x

Zhang J, Nielsen SE, Grainger TN, Kohler M, Chipchar T, Farr DR. 2014. Sampling plant diversity and rarity at landscape scales: importance of sampling time in species detectability. PLoS One 9: e95334. DOI: 95310.91371/journal.pone.0095334.

Zhang W, Huang D, Wang R, Liu J, Du N. 2016. Altitudinal patterns of species diversity and phylogenetic diversity across temperate mountain forests of northern China. PLoS One 11: e0159995. DOI: 0159910.0151371/journal.pone.0159995

Zietsman MM, Bredenkamp GJ. 2007. Threatened Limestone Fynbos plant communities of Andrew's Field and Tsaba-Tsaba Nature Reserve, Western Cape. Bothalia 37: 89-102. DOI: 10.4102/abc.v37i1.306. 